\title{
Some Principles for Library Planning
}

$\mathrm{T}$ Housands of library buildings have been built in the United States: public libraries, university libraries, college libraries, and special libraries. We have been building library buildings for a long time and, before we began, others were building them in older parts of the world. Yet it is almost a truism to say that the ideal library building has not been built. Indeed, it is more usual to discover that the newest building, lovingly and carefully planned, develops major faults as soon as its doors are opened, and that these faults grow in number and seriousness as the years go by. Why should this be so? Surely, librarians know well enough what they need. Surely, architects are clever enough and ingenious enough to know how to give it to them. Why has it not happened that the ideal library building has been built? This is a simple question, but the answer to it, unfortunately, is not simple. The answer is exceedingly complex. In this complexity are two sorts of considerations. One sort should not be there at all, because it is unreasonable. The other sort should not be there, either-but there is more excuse for its presence.

The unreasonable element may be disposed of first and then, perhaps, forgotten - forgotten, that is, except to remember that it is an ever possible bugbear which needs always to be dispelled by the bright light of reason before the serious business

1 Paper presented at the meeting of the Association of College and Reference Libraries, Buffalo, June 18, 1946. of planning is commenced. The devising of a suitable library building is difficult enough without fatally handicapping the deviser at the beginning.

I am sure you all know what I mean. If we are to build a library building, surely it is nothing more than common sense to begin with a clean sheet of paper on which to draw our plans and not with a sheet already marked with encumbering lines placed there by someone to whom the ultimate purpose of the building is a secondary consideration. I am speaking, of course, of the donors-the ladies and gentlemen with the cash, may the good Lord bless thembe they individuals, boards, or communities. There is a lesson they need to learn. A library, my worthy friends with the open moneybags, is a library. It may also be a monument, if you will. But if it be a monument, its primary dimension should be measured in service and not in stone. A library is a monument worthy of the name because of what goes on inside its walls, not because it makes an imposing subject for a picture postcard.

Perhaps you believe this is not worth mentioning. Look about you at the mausoleums labeled "library," and ponder on the fact that even today an eminent architect is struggling with the plans for a great university library which must have white columns against red brick on all its sides, because the good lady said so in her will.

So much for the unreasonable element. Let's turn now to some things which make 
sense. But before we do so, let's state a principle for good library planning. We can do it very neatly in a paraphrase of an ancient axiom. Let's say that a donor's money should be seen and not heard-and let it go at that.

We are ready now to consider some of the reasonable reasons why the ideal library building has yet to be built, even after all these centuries of building. And here we are brought up short. Possibly we are wrong. Possibly the ideal library building has been built. Possibly the library of Alexandria, or the great Muslim Library of ninth-century Bagdad, or the library burned by the zealous Ximenez in Cordova in $\mathbf{1} 492$ - perhaps one or all of these were perfect libraries. Perfect, that is, in their timebut not perfect if they existed today. For a library building is perfect only in the present, not in the past. Nothing is newer than a library ; nothing reflects more vividly -or, nothing should reflect more vividlythe ever-changing character of the agencies of written communication of knowledge and the uses to which they are put. So, a primary principle of library planning should certainly be modernity. In some public buildings we may be able to indulge ourselves with the inefficiency of medieval architecture for the sake of its esthetic appeal. We cannot afford to do this in our libraries.

We will not, if we begin our planning at the right end. A library, like a factory or a school or a home or a theatre, is a place where something happens. It is a building constructed for a purpose; an edifice erected to perform a function. Since this is true, there is only one way in which it can be properly planned. It cannot be planned from the outside in; it must be planned from the inside out. One may not begin with a Greek temple, or a Gothic cathedral, or a copy of Magdalene College-however beautiful each of these may be-and put a successful library inside. One must begin with the library itself and build this first, and then put a wall around it to keep the weather out. The result of such a process, honestly performed, cannot help but be beautiful, with the honest beauty of function fulfilled-the same sort of beauty that we find in the airplane or the battleship or the motor car, the same sort of beauty that we find, if we are honest with ourselves, in the modern factory building.

\section{Purpose for Which It Is Built}

I should like to make two points here, in passing. The first of these I have already made by inference. It is this. The best architecture being planned today is factory architecture. This is true because the builder of a factory is interested in only one thing: to erect a building which will best serve the purpose for which it is built. When he does this, without cavil, he produces a beautiful building. He produces a building which is beautiful because its usefulness is apparent, because it translates into structure the purpose for which it has been built. A library should do the same thing. To put it simply, a library should look like a library. Why not? Are we, after all, so ashamed of our profession that we wish to make its home look like something else? Must we apologize in stone and bricks for the activities that go on behind the walls? Must we all put signs on our buildings, as the librarian of one great university wishes to do-signs reading "The books are on the inside?" Is there no beauty in librarianship, in efficient service to a questing public, which should be embodied in its house? If a church is what you want, by all means build a church-and worship in it. If a tomb is what you want, by all means build a tomb, and wither in it. But if a library is what you want, then build a library! 
The other point I wish to make here, in passing, is this. Many of the elements in the architectures we copy today were functional once, but are functional no longer. We have lost sight of the reason, in our reverence for the form. This is a symptom of decadence - this worship of form beyond reason. It is a decadence we cannot afford in purposeful architecture. It marks us as builders who have not thought through our problems, who have not been willing to make use of the valuable contributions of science to the solution of our problems, who have been content to apply the solutions of yesterday to the problems of today. Believe me, those old builders whom we ape never did this. They built the best they could, using all the knowledge and all the ingenuity they could muster and daring to experiment with new forms when new forms met a need. They were realists, those old gentlemen. There was nothing decadent about them.

\section{Useless Survivals}

Let me give you a simple example of what I mean. Before the invention of modern means of artificial illumination and modern systems of ventilation, it was necessary to have large window openings. The only way to get large window openings was to have high ceilings, so there would be space for light and air. Thus, you see, high ceilings were functional and necessary. It was only by means of high ceilings that large floor areas could be lighted and large rooms could remain habitable from the standpoint of air to breathe. This was a handicap to the builder, because it meant that buildings had to be tall. In order to get light and air, a great amount of building cubage had to be constructed which had no other useful function than to furnish light and air. Our long association with rooms of this type has conditioned us to an extent to be- lieve that ceiling height bears some necessary architectural and esthetic relationship to floor area. And so we go on building high-ceilinged rooms and wasting cubage which costs money to build and more money to heat and maintain, for a reason which has disappeared with the advent of adequate artificial light and adequate ventilation. I believe Michelangelo would have laughed at us-perhaps he is laughing at us, in some Parnassus of architects dead and gone-for he was a practical man and no apostle of decadence.

What a contradiction of purpose it is, after all, to build a lofty ceiling and then hang our lights on long chains from it to get them close enough to our tables to be of use! What is the function today of all that space above our heads? What library activity is it that goes on more than eight feet from the floor that makes this barnlike elegance obligatory? Or is it that we are afraid of the appearance of low-ceilinged rooms, well-lighted and well-ventilated with clean fresh air? If it be this fear that restrains us, then we are suffering from the same subtle malady that caused early motor car manufacturers to provide their horseless carriages with leather dashboards and whipsockets. It is high time library architecture moved out of the horseless carriage era. It isn't necessary, perhaps, to go as far as Buckminster Fuller's Dymaxion car, all at once. But at least, let's get in line with Ford and Chrysler.

\section{Must Keep Up with Change}

All that I am saying is that things have been moving in the construction business. We can do a great many things today that were impossible yesterday. We don't have to do a great many things today that were necessary yesterday. To fail to do the things we can do and to go on doing the things we no longer are required to do is to 
give a negative shake of the head to progress. It is worse than that. It is to give reason to the caricaturist's favorite prototype of the librarian as an elderly person whom the world has somehow passed by and left stranded amid the cobwebs and dust of a vanished civilization.

But it will be just as fatal to be modern in our architecture only because modern architecture appeals to us, as it would be to be medieval because we happen to like medieval buildings. I want to sound this warning because I believe there is sometimes a danger of being hypnotized by gadgets. The world - the modern world-is full of gadgets, very interesting gadgets. Novelty alone is never an excuse for their incorporation into a building plan, any more than tradition alone is an excuse for their neglect. Libraries, I repeat, are functional buildings. Every possible means should be used to make them as able as possible to fulfil their functions, whether that means be as new as tomorrow's sunrise or as old as yesterday's newspaper. The test of value is usefulness, not newness or age.

So, a primary principle in library planning is certainly to begin with a study of building function. This is so elementary that it seems silly even to state it. Every librarian who has ever built a building has begun with a list of the things he wanted the building to do. No one but a fool would do anything else. All of this is quite true. But, unfortunately, after he has begun with such a list, he has not always been true to it. Too often he has compromised. He has been afraid of the consequences of his convictions. He has a pattern in his minda pattern inextricably entangled with a priori ideas of beauty and traditional form - and he unconsciously squeezes and trims his functional plan to fit this pattern. The very language of library planning is a dead giveaway of this. "How large a stackroom do I need ?" "How many seats must I have in my reading room?" This is not functional language. This is pattern language.

\section{Functional Building}

A library is a place where books are used and where books are stored. That is functional. But books do not have to be used in a reading room; and books do not have to be stored in a stackroom. It is altogether possible that the perfect library will have neither of these, in the sense in which the terms are generally understood. Do you see what I mean? I am not for a moment trying to say that reading rooms and stackrooms have no place in a modern library. I am only asking that we begin at the beginning in our planning, and not in the middle. I am only saying that the first questions to answer are "How is reading best done in this situation, and how are books best stored?" If the honest answer is a reading room and a stackroom, then build a reading room and a stackroom. If the answer be something else, then build something else. Build what is needed, because it is needed; not what is traditional, because it is traditional.

"But if I do this," you may say, "it won't look like a library." Stop and think for a moment. A library is a place where books are used and where books are stored. If you build a building in which books can be used and books can be stored, you will build a library. And if you build a library, I'll bet it will look like a library. And if you build a building in which books can be used better and stored better than they have ever been before, it will look like a better library than has ever been built before. It may not look like the library Whoozis University built in I9ro. Why should it?

So, the primary principle of good library planning is first to find out what you need and then go ahead and build it. And the 
second principle is just as simple. Make up your mind before you start that what you need you can have and don't quit till you get it. Don't be put off by lazy architects or unimaginative contractors. Don't let anybody tell you that what you want is impossible, because it isn't. The technique of modern building, with its wealth of materials and its myriad of ways of doing things, is inexhaustable in its possibilities. It can be done, no matter what it is, if it needs to be done. Let me show you what I mean.

\section{An Example}

There are in this country hundreds of libraries-and this is an understatement if I ever heard one-hundreds of libraries which are quite adequate from the standpoint of size, if that size be measured in cubic feet. Yet they are inadequate because those cubic feet are misdistributed. There's enough cloth for the suit, but the coat is too long and the pants are too short and the waistcoat hangs too low and won't come together over the tummy. No one is to blame. Nothing is to blame, nothing except the inexorable change which is inseparable from progress. How could one expect anything different from this? If twenty years ago books were used in such and such a way, and library materials were of such and such a character, and library patrons acted in such and such a manner, and a building was carefully planned to embrace the needs created by all these things, a good library was built-twenty years ago. But if twenty years later the character of library materials has changed, and the character and pattern of their uses have changed, and the patrons act differently and want different kinds of things for different reasons, and new functions have been created and older functions have disappeared, then this library building which was so perfect then falls far short of perfection now. And the more carefully and efficiently it was planned to fulfil the needs of yesteryear, the less well suited it is to fulfil the newer needs of today and tomorrow. The great Bait al-kutubthe House of Books-built by a caliph of medieval Bagdad was a wonder of its day, Scholars composed rhapsodies concerning its elegance and the treasures it contained. But a large proportion of its floor area was taken up with sleeping rooms for its patrons, and a major function of its staff was to feed the scholars who thronged to study its books, and a considerable item in its budget was for the purchase of paper and ink for the copying of manuscripts. None of these things is important in modern library economy. The building which housed the House of Books would scarcely be considered an efficient library structure today.

\section{Growth Is Unpredictable}

What is so strikingly apparent when viewed over the panorama of centuries is evident as well in the space of a relatively few years. It is a foolish man today who believes that he can foresee the structural needs of librarianship twenty or even ten years hence. We have learned better. We have learned that to make functional space provisions on the pattern of today is more likely than not to lead to a misfit building tomorrow. We have learned that it is impossible to foresee in which directions the needs for space will grow. We have learned that the direction of library growth is unpredictable, except in general terms. One thing we do know, beyond any doubt-a library will grow. It will grow in size and in activities, but where it will grow we cannot prophesy. Even more than the human figure, the library needs a two-way stretch.

And yet, we must build. We must construct buildings, and in order to construct 
them, we must plan them. We must plan them to fit neatly the needs of today and susceptible of easy adaptation to the needs of tomorrow. At first sight, this appears to present a dilemma. But modern building technique has an answer. This answer is not a new one in the building field; it has been used for decades in the construction of industrial buildings. Perhaps as good a name for it as any is "adaptable construction." Adaptable construction is simply a type of construction which furnishes a maximum of free space within the enclosing walls. This means space which is adaptable to the needs of the moment, without the necessity of expensive and messy alterations. It means engineering the building in such a way that any square foot of floor space may be used for any purpose.

Under this system of construction, the old terms of reading room and stackroom and catalog room and reference room disappear from the vocabulary. A library building becomes simply an area of usable floor space surrounded by walls. What individual units of this floor space are to be used for depends upon the needs of the time. A given square foot may be part of reader space today; it may be used for book storage tomorrow; and five years hence it may be a corner in a professor's study room. All of this is brought about by improvements and innovations in structural design. It requires that all portions of the floor area be of uniform strength; that they may be heated, ventilated, and lighted according to the uses to which they are put; and that the introduction of partitions or the removal of partitions or changes in lighting or ventilation shall be neither difficult nor costly. This would have been impossible not many years ago, but we have learned how to do it today. The prerequisites have been many. They have been such things as new conceptions of structural members fabricated of steel; new systems of ventilation without separate ducts which have been an everpresent barrier to easy building alteration; new ideas of floor construction to bear the heavy weight of massed bookstacks today and the lesser weight of readers and students tomorrow, without undue floor thickness or undue cost; new and more efficient systems for lighting which work as well in stackrooms as they do in reading rooms; and soundproof dividing walls independent of the structure which may be moved at will to give new space divisions without interfering with the electrical or heating or ventilating systems. All of these things are possible today-and they have set the library planner free from the bugbear of obsolescence. Along with them have come bookstacks independent of the structure, which may themselves be moved from one part of the building to another easily and quickly. And all of this may be constructed today with a minimum of fuss and bother, and changed the day after tomorrow as easily as it was built at first. This is true because the technique employed is what the builder calls "dry construction," to distinguish it from a construction in plaster and mortar which requires the use of wet materials and which is set and unchangeable when it has been completed.

\section{Future Possibilities}

These improvements in construction technique have brought with them great possibilities in the more efficient utilization of space in buildings. Because artificial light and air conditioning are now relatively perfected, it is no longer necessary to depend upon lofty ceilings and large window openings for light and air. Five stories of usable, comfortable, and efficient space may now be built where only three could be built before. For the same reasons, space-eating courtyards and light wells are no longer 
necessary. Because floors can now be built economically to carry any reasonable load, separate stackrooms which immediately freeze the design of a building rigidly need no longer be built and the book storage space may expand in any direction within the building. S It becomes more simple to achieve a desirable intimacy between the reader and the book by scattering reading areas throughout the book storage space or by placing larger numbers of books in reading rooms.) Because dividing walls may be moved at will, it is no longer necessary to build structures of larger floor area than immediately required in order to be certain of meeting needs only guessed at. The library building, inside, now has the possibility of fluid growth, without hindrance; and this fluidity is transferred to the outside of the building, since nothing in the interior plan any longer makes it necessary to build additions in one direction rather than in another. Indeed, with modern materials it is altogether possible to make the outer walls of the building themselves adaptable, so that a whole wall may be removed without disturbing the structure and its material reused in an enlarged building.

\section{Less Expensive}

And the cost? Generally, desirable things come high. In this case, however, we are agreeably surprised. Far from increasing the cost of efficient building, modern building technique has generally made it somewhat less expensive. Competent estimates show that a given number of books, for example, may be accommolated in a structure like the one I have been describing for a little less than would be possible in a traditional building. And, if one takes into consideration the added efficiency and the added serviceability of such a building, the cost begins to appear surprisingly low. It is altogether possible to construct a library building, completely lighted and air conditioned, and including its equipment and its furniture, for very little over one dollar a cubic foot; and in larger structures, where the advantages of prefabrication in quantity count greatly, this price can be substantially lowered. And when you have finished, you have a building which is good not just for the needs of today, but which can be adapted quickly and easily and inexpensively to the new needs of next year and the year after, and which all of the time will function as an efficient library plant, making service easy, and multiplying the chances for the library organization to realize to the utmost the possibilities inherent in the profession. You can indeed today build the library of tomorrow.

So, I have tried to give you two major principles for library planning. The first of these is, find out what you need and then build it. Think in terms of function and forget old patterns. Do this without fear that the result will be something other than a library, only because it may not look like the buildings we call libraries today.

The second principle is, when you know what you need, don't give up and don't compromise until you get it. It is not beyond your reach. Anything reasonable is possible. Building construction has made great strides in recent years, strides made possible by new materials and new handling of older materials. On these I have only been able to touch. To enumerate and describe them all would require far longer than the time I have. But we live in an age in which material things are our servants. Science and technology have opened up a world in which all things are possible. Some of them may take some doing, but they can be done. It requires imagination and enterprise and a willingness to experiment, but what you want you can have. So why not go out and get it? 